\title{
Poverty: Place of Agricultural Development on Economic Growth of Nigeria
}

\author{
Oyeyipo Eyitayo. $\mathrm{J}^{2,3,4,5 *}$, Oluyemi Faith $\mathrm{F}^{5}{ }^{5}$, Iwelumor, Oluwakemi ${ }^{2,3,5}$, Osijo, Busayo.B ${ }^{6}$, Oye Olubukoye O. ${ }^{1,3,4,5}$ \\ Olorunmola Jide J. ${ }^{7}$, Oyekola Isaac A. ${ }^{1,3,5}$ \\ ${ }^{1}$ Landmark University SDG 1 (No Poverty) \\ ${ }^{2}$ Landmark University SDG 3 (Good Health and Well-being) \\ ${ }^{3}$ Landmark University SDG 10 (Reduced Inequality) \\ ${ }^{4}$ Landmark University SDG 16 (Peace and Justice, Strong Institution) \\ ${ }^{5}$ Landmark University, Omu-Aran, Kwara State, Nigeria \\ ${ }^{6}$ Tai Solarin University of Education, Ijebu Ode, Ogun State, Nigeria \\ ${ }^{7}$ Nigerian Correctional Centre. \\ *Corresponding Author
}

\begin{abstract}
No society attains development where poverty and economic insecurity prevail. This article examines poverty with the place of agricultural development on the economic growth of Nigeria. It aims at examining the importance of agricultural growth on sustainable development while also looking at the barriers to effective economic growth through agriculture. Agriculture has always been a major boost in Nigeria's economy from inception until the shift from agriculture to oil production which has brought about the declining trend of growth in Nigeria.
\end{abstract}

The study adopted a survey as the design for the study. The Cluster sampling technique was employed in this study. 200 respondents carefully arrived at on referrals from farming associations in Kwara state made up the sample size for the study. The study gathered data from the study population through questionnaires and such data collected were analyzed using simple percentages and frequency tables so as to reach conclusions to the issues being addressed.

Findings from the study reveal that majority of the respondents have no tertiary education and thus practice traditional methods of farming. It also brought forth that agriculture, as practiced by the majority of the respondents, is a vital tool to reducing unemployment but not able to reduce poverty. It sees lack of support from the government as a blow to the interest of the youth in Agriculture

It, therefore, suggests that for the economic growth of Nigeria to be repositioned, the nature and manner in which agriculture is practiced should be reviewed and government intervention should be intensified.

Keywords: Poverty, Agriculture, Development, Economy

\section{INTRODUCTION}

A griculture is a vital role in the economic growth of a nation (community), not only does it spur national development but it facilitates the industrial development of a nation. Unlike before, a lot of individuals are now engaging in agricultural practices in Nigeria which has in turn improved the economy of certain areas if not all. Many Nigerians live and work in rural areas. Almost $75 \%$ live in rural areas compared to less than $25 \%$ living in urban areas. In the same vein, over $58 \%$ of the workforce is involved in agriculture (Yusuf Aremu, 2014).

The history of Nigeria cannot be told without the mention of agriculture. The agricultural record is entangled with the nation's political record, which explains the green in the National flag. In the early times, our predecessors depended mainly on farming as a means of survival, as a result, they generated a lot of produce to sustain themselves and society.

Agriculture in Nigeria is a branch of Nigeria's economy that, as of 2010, provides employment for about 30 percent of the population (Labour Force Statistics, 2010). Commercialization at the small, medium, and large enterprise levels is changing the industry (Olomola, 2007). Nigeria as a country is dependent on agriculture. However, in the 1970s Nigeria drifted to oil exports majorly and after years of slow economic growth, there was the need to go back to agriculture. The Nigerian economy was severely affected by the shock caused by the fall in the price of oil. As annual GDP growth declined to 2.7 percent from 6.2 in 2014, the economy slowed down drastically in 2015. The Nigerian economy experienced its first recession since 1991 in 2016, As the oil production shortage prolonged due to activities of Niger Delta militants and a decrease in oil prices, the growth of -1.5 percent was reported. In particular, the underperformance in the oil sector has spread to the non-oil sector through the exchange rate channel, with the non-oil sector contributing $0.2 \%$ to its worst performance since 1984. However, the Nigerian economy exited its recession in the second quarter of 2017, posting a positive growth rate of 0.5 percent. (Nevin, 2017). The emphasis place majorly on industrialization for strategies has made agriculture and rural areas to be ignored.

The majority of the indigent but energetic citizens live in rural areas and take part in agriculture predominantly. Nigeria as a country is an agricultural county with immense land and natural resources, nearly all the states in Nigeria are blessed with one or more natural resources. However, Nigeria has 
solely depended on oil, for the most part, neglecting other natural resources which when put to good use could yield lots of increases in the nation's economy. Despite the articulation of government policies, strategies, and programs and the commitment of governments and donors to the broader sustainable agriculture and rural development framework, Nigeria's rural communities remain underdeveloped and much complex design, implementation, and monitoring and evaluation problems remain unresolved (Bakare, 2013).

Agriculture is not only important for a nation as a source of food security and reserves but as a means of creating more employment opportunities. In a study (2014), the World Bank concluded that agriculture has been the key source of profitable employment in many developed and developing countries, a simple food supply source from which the nation can feed its abundant population, a regenerative source of foreign exchange income, a means to supply local raw materials to the nation's industries, and a reliable source of government income. A large number of residents in Nigeria live in poverty and most of them are farmers or engage in agricultural activities. Boosting their profits would lead to less poverty percentage and thus an increase in the nation's GDP since a higher number of the population are in poverty. Development, as well as poverty, is measured by the growth in GDP and hence leads to further improvement in the economy. Therefore, this shows that development in the agricultural sector leads to a great improvement in the Nigerian economy. Although Nigeria is blessed with vast land and natural resources, the rate at which the agriculture sector is rising is very low.

\section{Problem}

The major source of income for people especially those living in rural areas is agriculture and most importantly farming. Due to the vast land and open space in the area, this allows for vegetation and effective participation in agriculture. As earlier stated, Nigeria is blessed with massive land and resources but it has not been maximized fully.

Nevertheless, the government came up with different policies and programs, and in the end, these agricultural policies illustrated the importance of Agricultural development on the nation's economy. In light of this, the government implemented a number of policies to further enhance the economy of the nation. Nevertheless, the structure put in place by the government to address economic issues such as poverty and unemployment has not yielded significant importance because of some barriers evident in agricultural practices. The following are some of the issues faced by the agricultural sector:

1. Agriculture in Nigeria is mainly practiced by farmers in rural areas and these farmers produce on a small scale. The fact that these people are meant to provide for $90 \%$ of the food consumed by Nigerians is absurd as they only produce at a subsistence level.
2. Lack of storage facilities for agricultural products has led to wastage and high cost of storage space.

3. Dependence on the weather for irrigation purposes. Farmers still depend on the weather; rainfall instead of adopting irrigation systems that supply water throughout the year.

4. The agriculture sector is poorly financed in Nigeria which hinders the agriculture sector from developing and in turn hampers the economy of the nation.

5. Lastly, dependence on imported products. Nigeria has relied much on imported products than actually producing locally in the nation.

This study, therefore, becomes necessary to understand how effective agriculture is to the growth of a nation and its economy as well as to enumerate barriers negating against the purpose of agriculture in Nigeria.

\section{Objectives}

The study is of three objectives which are:

1. Examine the effects of Agricultural development on economic growth.

2. Examine the barriers deterring Agricultural development and economic growth.

3. Study the ways agriculture can be improved to influence economic growth.

\section{CONCEPT OF AGRICULTURAL DEVELOPMENT}

Agricultural development refers the involvement in agricultural activities and the use of modern methods or machines in carrying out these activities. In other words, the practice of mechanized system in the agricultural sector. Also it is the involvement in agricultural practices and the ability to come up with an improved method of agricultural production, as well as areas that are concerned with agricultural practices. Agricultural development is a prerequisite for development and economic growth especially rural development. The economic growth and food security of any nation is dependent on the development of agriculture as it plays a major role. Yet, as the population of the world grows and migration to cities intensifies, the proportion of people who do not produce food may increase (Cardino, 2017).

Agricultural development is a multi-stakeholder activity which encourages and encourages positive change in rural and urban areas (Nwachukwu, 2008). It is mainly concerned with the material and social development of people in a particular area. Using the 20-20-20 plan as guideline, Nigeria strives to become a prominent economy in Africa and a leading country in the world's political and economic sectors. In order to develop the nation's economy, Nigeria needs to focus on vital sectors of the nation, most especially the agricultural sector. Nigeria will boost its economic growth in the coming decade by concentrating on agricultural production (Omoregbe, 2014). 
Adegoye \& Dittah (2014), states that a fully developed economy, especially in the agricultural sector, means an increase in export crop production, with an improvement in the quantities and grades of such export crops. However, for a country to industrialize, if agriculture can supply sufficient materials to agro-allied industries, agricultural production can be said to have acquired growth. In addition, Agricultural development can be linked to more extensive issues of development and growth, food security and the ability to utilize natural resources.

\section{Benefits of Agricultural development}

Increased participation in agriculture helps to improve the social and material welfare of the people which in turn promotes the economy of such location. Hence, the advantages of participating in agriculture are as follows;

\section{$>$ Quality standard of living.}

Agricultural development helps to improve the quality of life of people especially in rural areas. As agriculture is the general profession of people in rural areas, Agricultural development is such area ensures enough food for present and future generations, helping such community to exceed subsistence level of production. It also helps to generate sufficient income for farmers and those involved in other agricultural practices such as fishing, forestry, rearing of animals, etc.

\section{$>$ Productive capacity for the future.}

Agricultural production also benefits the country by ensuring and retaining potential productive capacity, as well as increasing productivity without jeopardizing natural resources or harming the environment. It also necessitates appreciation for and acknowledgement of local expertise and natural resource management, as well as efforts to improve current generations' capabilities without jeopardizing future generations' prospects. Farmers can feed their families, send their children to school, provide for their families' wellbeing, and invest in their farms as they produce more food and gain more money, making their communities economically stronger and more prosperous for agricultural growth.

\section{$>$ Employment Opportunities.}

Agricultural development also helps to tackle the issue of unemployment in a nation. It provides employment opportunities for people especially in the rural area, even on a large scale in both second and third world countries, i.e. developing and underdeveloped countries. It is an essential source of livelihood that should not be taken lightly. The increasing agricultural production that leads to the rise in agricultural surplus helps to promote social welfare, particularly in rural areas.

\section{$>$ Reduces Poverty and Hunger}

Agricultural development helps to curb poverty and hunger in a nation by coming up with policies that promote food security. Also, it improves the sustainability of livelihood of people in a particular community.

As a result, agricultural growth must include economic and environmental sustainability, adequate farmer income, potential productive capacity, enhanced food security, and social sustainability. (European Commissions, 2018)

\section{How can Agricultural development be improved?}

Agricultural development is meant to bring about transformation in agriculture industries and yield more profit while it does not put the natural environment in jeopardy.

According to Joseph Stiglitz (2015), Agricultural development can be improved by following the steps below;

i. Carrying out research relating to resources. Designing or creating information for stakeholders and the farmers.

ii. Research and development in the fields associated with organization and partnership amongst individuals conducting research, producing crops etc.

iii. Designing projects for the estimation of crop yield. Also applying and transferring technology.

iv. Pests management, certification and projection for specific manner of land usage, providing financial aid, etc.

Agriculture production includes resource planning, pollution problems, and projections or evaluations of the most up-to-date agricultural technologies. It comprises a range of federal and local agricultural initiatives aimed at supporting agricultural production.

\section{Agriculture in Nigeria}

Nigeria has always been involved in the practice of agriculture. In the 1970s, Nigeria became dependent on oil exports. However after experiencing years of slow economic growth in the nation, it became clear we had to refocus on agriculture. Nigeria suffers from the resource curse (Aluko, 2004; Otaha, 2012). The current state of the economy is devastating taking into consideration the endowment of natural resources and human capital in the nation.

Nigeria is blessed with vast land. Around a total of 31 million hectares of land are uncultivated, and the varied climate allows for the development of a wide range of goods from tropical and semitropical regions around the world (Chauvin, Mulangu and Porto, 2012). How ironic is the fact that the nation is ranked among the world's poorest. The agriculture sector has served a buoyant support for Nigeria since independence. Nigeria was listed as the world's largest exporter of groundnut, for cocoa and palm produce, Nigeria was the second largest exporter and also for cotton and rubber, according to Sekunmade (2009).

Nigeria's agriculture sector is yet to make use of the available potential at their disposal, in terms of labour, water, land etc. According to the Federal Ministry of Agriculture and 
Rural Development, as at 2012 only $40 \%$ of the estimated 84 million hectares of vast land is under cultivation, neglecting the $60 \%$ that has potentials for agriculture. Due to lack of equipment and ancient farming method, productivity is quite low which in turn resulted to Nigeria's dependency on food importation. Nigeria has a diverse and rich vegetation that can sustain a large livestock population, as well as irrigation capacity with 267.7 billion cubic meters of surface and 57.9 billion cubic meters of underground water, respectively. (Chauvin, Mulangu and Porto, 2012; Lipton 2012). The nation's ever-increasing population however helps to bring about capacity for increase in productivity.

Notwithstanding, the agriculture sector in Nigeria remains stagnant and unprogressive. One of the reasons for this may be due to lack of farming equipment and machines that can help improve agricultural practices and make it easier for farmers and people involved in other agricultural practices. Nigeria strives for Agricultural development and still makes use of primitive methods of production, its negative effect is quite evident on the level of production of the nation as we still depend on food imports and are still unable to produce above the subsistence level. According to Falola \& Haton (2008), the bad state of the agriculture sector is as a result of oil superfluity and its consequences.

More important is the fact that the agriculture sector needs the effectiveness of its subsectors in order to promote economic growth as the subsectors have a key role to play in the production of raw materials as well as preserving the environment. Be that as it may, one of the major cause of the failing economy is low productivity in the agriculture sector. Slow growth in the agriculture sector, according to Iyoha and Oriakhi (2002), is due to low capital per worker growth rather than low Total Factor Productivity (TFP). Because of a lack of resources and an ever-growing population and labor force.

According to the Federal Ministry of Agriculture and Rural Development (2012), by 2015, the agriculture value chain will provide 3.5 million jobs, raise farmers' incomes by $\$ 2$ billion, and reduce food insecurity by 20 million metric tons (MT) of additional food supply. Increased production and agricultural growth are the only ways to do this..

\section{METHODOLOGY}

This study is descriptive and inferential in nature. Descriptive in the sense that it examines the place of agriculture in Nigeria and inferential in the aspect of drawing inferences from data collected. The research design is survey. The survey research design is significant to this study as it gathers data from the study population through questionnaires and such data is subjected to statistical analysis so as to reach conclusions to the issues being addressed. Kwara State form the study location .with an area of $765 \mathrm{~km}^{2}(295 \mathrm{sq} \mathrm{ml})$ and a population of 777,667 persons as at 2006 , making it the $7^{\text {th }}$ largest city by population in Nigeria with geographical coordinates $8^{\circ} 30^{\prime}$ North, $4^{\circ} 33^{\prime}$ East.
.The Cluster sampling technique was employed in this study. It is a type of sampling method. It is efficient for its ability to divide the study population into groups or clusters and conduct analysis on information gotten from the sampled clusters. The sample groups or clusters are obtained using the simple random sampling. The sampling method was used to arrive at 200 persons in Kwara State for the collection of data. The sample size was carefully arrived at on referrals farming associations in Kwara state

The method used in collecting data for this study is the quantitative method of data collection with open-ended and close-ended questionnaire. Also, the distribution of questionnaires was based on referrals from other respondents. Data collected were analysed using simple percentages and frequency tables.

\section{Ethical Considerations}

As this study is carried out for academic purposes and acquisition of knowledge, emphasis is placed greatly on the respondents' disposition and a trusting relationship was ensured, as communication was planned and managed meticulously so as to minimize risks and maximize knowledge. Voluntary consent of the respondents were sought and gotten verbally before commencing the research.

\section{FINDINGS}

Table 1: Age group of the respondents

\begin{tabular}{|c|c|c|c|}
\hline & Frequency & Percentage & Cumulative Percent \\
\hline Below 20 years & 39 & $19.5 \%$ & 19.5 \\
\hline 20-39 years & 125 & $62.5 \%$ & 82 \\
\hline 40 and above & 36 & $18 \%$ & 100.0 \\
\hline Total & 200 & $100 \%$ & \\
\hline
\end{tabular}

Field Survey, 2021

The table above reveals the age distribution of the respondents and it shows that $39(19.5 \%)$ of the respondents are below 20 years, $125(62.5 \%)$ are between the ages of 20 and 39 years and the rest (36) are 40 years and above. Also, majority of the respondent are between the ages of 20-39 years which falls within the bracket of active youth.

Table 2: Sex Distribution

\begin{tabular}{|c|c|c|c|}
\hline & Frequency & Percentage & $\begin{array}{c}\text { Cumulative } \\
\text { Percentage }\end{array}$ \\
\hline Male & 131 & $65.5 \%$ & 65.5 \\
\hline Female & 69 & $34.5 \%$ & 100 \\
\hline Total & 200 & $100 \%$ & \\
\hline
\end{tabular}

Field Survey, 2021

The respondents age distribution able above shows that 131 $(65.5 \%)$ of the respondents are male and $69(34.5 \%)$ were female. It can be deduced from this that most of the respondents are male at $65.5 \%$ of the total respondents. This may be likened to the fact that majority of persons engaged in 
agricultural practices are dominated by men as seen in the membership of Agricultural Unions while few women engage in agriculture but rather sell produce from the farm.

Table .3: Marital Status

\begin{tabular}{|c|c|c|c|}
\hline & Frequency & Percentage & $\begin{array}{c}\text { Cumulative } \\
\text { Percentage }\end{array}$ \\
\hline Single & 56 & $28 \%$ & 28 \\
\hline Married & 143 & $71.5 \%$ & 99.5 \\
\hline Widowed & 1 & $0.5 \%$ & 100.0 \\
\hline Total & 200 & $100 \%$ & \\
\hline
\end{tabular}

Field Survey, 2021

The table on the marital status of the respondents reveals that that $143(71.5 \%)$ of the respondents are married making up majority of the respondents while, $56(28 \%)$ are single and 1 $(0.5 \%)$ is widowed.

Table 4: Ethnic Group

\begin{tabular}{|c|c|c|c|}
\hline & Frequency & Percentage & $\begin{array}{c}\text { Cumulative } \\
\text { Percentage }\end{array}$ \\
\hline Yoruba & 161 & $80.5 \%$ & 80.5 \\
\hline Igbo & 17 & $8.5 \%$ & 89 \\
\hline Edo & 7 & $3.5 \%$ & 92.5 \\
\hline Others & 15 & $7.5 \%$ & 100 \\
\hline Total & 200 & $100 \%$ & \\
\hline
\end{tabular}

Field Survey, 2021

The table above is showing the distribution of the respondents' ethnic group and it reveals that, $161(80.5 \%)$ were from the Yoruba tribe, 17 (8.5\%) were Igbos, 7 (3.5\%) are Edo and $17(7.5 \%)$ consists of other tribes such as Igala, Ebira, Nupe and Hausa. It can therefore be deduced from this table that most of the respondents are Yoruba and this could be as a result of the fact that Kwara state is a Yoruba dominated state but with more than seven ethnic groups residing in the state.

Table 5: Educational Qualification

\begin{tabular}{|c|c|c|c|}
\hline & Frequency & Percentage & $\begin{array}{c}\text { Cumulative } \\
\text { Percentage }\end{array}$ \\
\hline $\begin{array}{c}\text { Primary } \\
\text { Education }\end{array}$ & 5 & $2.5 \%$ & 2.5 \\
\hline SSCE & 104 & $52 \%$ & 54.5 \\
\hline ND/HND & 28 & $14 \%$ & 68.5 \\
\hline BSC/MSC & 60 & $30 \%$ & 98.5 \\
\hline Others & 3 & $1.5 \%$ & 100 \\
\hline Total & 200 & 100 & \\
\hline
\end{tabular}

Field Survey, 2021

The table on respondents' educational qualification shows that $2.5 \%$ stopped at Primary Education which could be as a result of free education, 52\% are SSCE holders making up the majority, $14 \%$ are ND/HND holders, $30 \%$ are BSC/MSC holders. The data collected indicates that majority of the respondents $54.5 \%$ had no tertiary education.

The effects of agricultural development on economic growth

Table 6: How Much Respondents Earn from Agriculture Monthly.

\begin{tabular}{|c|c|c|c|}
\hline & Frequency & Percentage & $\begin{array}{c}\text { Culmulative } \\
\text { Percentage }\end{array}$ \\
\hline Below N30,000 & 90 & $45 \%$ & $45 \%$ \\
\hline $\begin{array}{c}\text { N30,000- } \\
\text { N59,000 }\end{array}$ & 72 & $36 \%$ & $81 \%$ \\
\hline $\begin{array}{c}\text { N60,000- } \\
\text { N89,000 }\end{array}$ & 28 & $14 \%$ & $95 \%$ \\
\hline $\begin{array}{c}\text { N90,000 and } \\
\text { above }\end{array}$ & 10 & $5 \%$ & $100 \%$ \\
\hline Total & 200 & 100 & 100 \\
\hline
\end{tabular}

Field Survey, 2021

The figure above on shows how the much the respondents make monthly from agriculture and this shows that $45 \%$ earn below N30,000 (less than 66 Dollars) from agriculture making up majority of the respondents, 36\% earn between $\mathrm{N} 30,000$ and N59,000 (between 66 Dollars and 132 Dollars), 14\% earn between N60,000 and N89,000 (between 133 Dollars and 198 Dollars) and 5\% earn above N90,000 (above 198Dollars). This implies that the majority of the respondents $81 \%$ earn less than $5 \%$ per day.

Table 7: Farming Method Adopted.

\begin{tabular}{|c|c|c|c|}
\hline Method & Frequency & Percentage & $\begin{array}{c}\text { Cumulative } \\
\text { percentage }\end{array}$ \\
\hline $\begin{array}{c}\text { Traditional(use of } \\
\text { machine ) }\end{array}$ & 151 & $75.5 \%$ & $75.5 \%$ \\
\hline $\begin{array}{c}\text { Modern (use of } \\
\text { hoes and cutlasses) }\end{array}$ & 49 & $24.5 \%$ & $100 \%$ \\
\hline Total & 200 & 100 & 100 \\
\hline
\end{tabular}

Field Survey, 2021

The table above shows the farming method adopted by the respondents. It can then be deduced from the above figure that $151(75.5 \%)$ of respondents make use of traditional methods while $49(24.5 \%)$ make use of modern methods in their agricultural practices which explains why very few respondents earn $\mathrm{N} 60,000$ and above as most people adopt traditional methods.

Table 8: Increase in employment opportunities through agriculture

\begin{tabular}{|c|c|c|c|}
\hline & Frequency & Percentage & $\begin{array}{c}\text { Cumulative } \\
\text { Percentage }\end{array}$ \\
\hline Yes & 187 & $93.5 \%$ & 93.5 \\
\hline No & 13 & $6.5 \%$ & 100 \\
\hline Total & 200 & $100 \%$ & \\
\hline
\end{tabular}

Field Survey, 2021

The figures above shows that $187(93.5 \%)$ of the respondents agrees that agriculture has increased employment opportunities, jobs such as farmers, managers in agro-allied 
industries, labourers, etc. while $13(6.5 \%)$ of the respondents disagree. Therefore, implying that almost all the respondents agreed that agriculture has increased employment opportunities but not to lift people out of poverty line.

Table 9: Has agricultural development help stimulate industrial growth?

\begin{tabular}{|c|c|c|c|}
\hline & Frequency & Percentage & $\begin{array}{c}\text { Cumulative } \\
\text { Percentage }\end{array}$ \\
\hline Yes & 140 & $70 \%$ & 70 \\
\hline No & 60 & $30 \%$ & 100 \\
\hline Total & 200 & $100 \%$ & \\
\hline
\end{tabular}

Field Survey, 2021

The table above shows how agricultural development has helped to stimulate industrial growth and it shows that 140 (70\%) respondents agree that agriculture has helped in stimulating industrial growth while $60(30 \%)$ disagree that agriculture has stimulated industrial growth. Therefore, majority of the respondents agreed that agriculture has helped in stimulating industrial growth such that there is an enormous growth on the demand for agricultural and agriculture-related products (crops, livestock, vegetables, eggs, furs and other livestock products) offered by various industries.

Table 10: If yes, in what way has agricultural development help stimulate industrial growth?

\begin{tabular}{|c|c|c|c|}
\hline & Frequency & Percentage & $\begin{array}{c}\text { Cumulative } \\
\text { Percentage }\end{array}$ \\
\hline $\begin{array}{c}\text { Provision of raw } \\
\text { materials }\end{array}$ & 40 & $25 \%$ & 25 \\
\hline $\begin{array}{c}\text { Employment } \\
\text { Opportunities }\end{array}$ & 49 & $30.6 \%$ & 55.6 \\
\hline $\begin{array}{c}\text { Exportation of } \\
\text { Agricultural products }\end{array}$ & 29 & $18.1 \%$ & 73.7 \\
\hline Boosts Economy & 42 & $26.3 \%$ & 100 \\
\hline Total & 160 & $100 \%$ & \\
\hline
\end{tabular}

Field Survey, 2021

The table above shows that $40(25 \%)$ of respondents agree that agricultural development has helped in the provision of raw materials such as grains, oil, steel, coal, minerals etc. $49(30.6 \%)$ believe that it has helped in providing more job opportunities such as farm manager, farm worker/labourer etc. $29(18.1 \%)$ agree that it has increased exportation of our goods that are not available in excess in other countries such as oil, coal, etc while $42(26.3 \%)$ believe it has helped in boosting the nation's economy.

The barriers hindering agricultural development and economic growth

Table 11 What are the barriers hindering agricultural development?

\begin{tabular}{|c|c|c|c|}
\hline & Frequency & Percentage & $\begin{array}{c}\text { Cumulative } \\
\text { Percentage }\end{array}$ \\
\hline Lack of finance & 76 & $38 \%$ & 38 \\
\hline $\begin{array}{c}\text { Inadequate agricultural } \\
\text { facilities }\end{array}$ & 89 & $44.5 \%$ & 82.5 \\
\hline Pests & 13 & $6.5 \%$ & 89 \\
\hline
\end{tabular}

\begin{tabular}{|c|c|c|c|}
\hline $\begin{array}{c}\text { Preference for white } \\
\text { collar jobs }\end{array}$ & 22 & $11 \%$ & 100 \\
\hline Total & 200 & $100 \%$ & \\
\hline
\end{tabular}

Field Survey, 2021

The above table indicates that $38 \%$ of participants believe that the issue of finance and the economy of the nation are barriers hindering agricultural development, $44.5 \%$ agree that the inadequacy of agricultural facilities such as land, structures and machinery, are barriers hindering agricultural development, $6.5 \%$ agree that pests and rodents hinder plants from growing well and this hinders agricultural development while $11 \%$ agree that the preference of youths for white collar jobs is one of the barriers hindering agricultural development in the state.

Figure 1: What are the challenges affecting the economy?

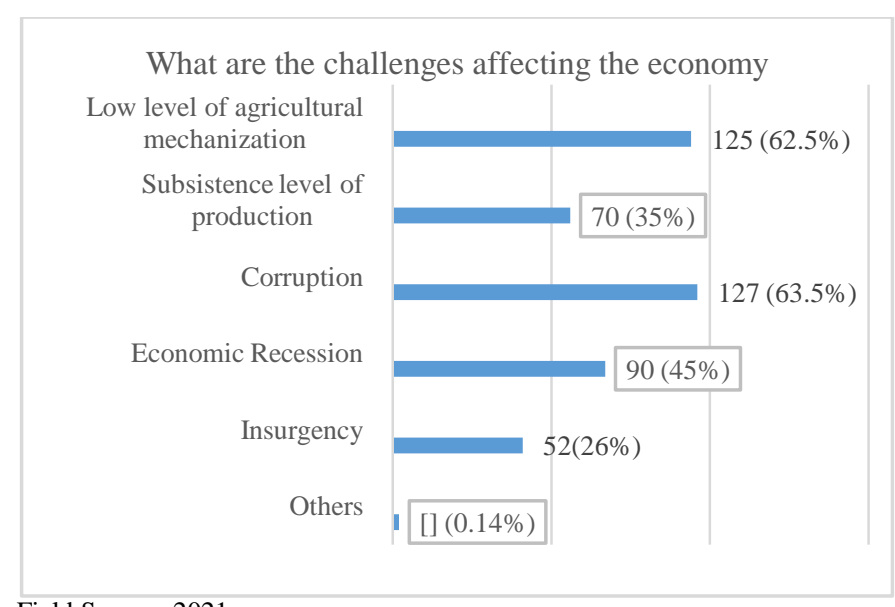

Field Survey, 2021

The Bar chart above on the challenges of affecting the economy shows that $125(62.5 \%)$ of the respondents agreed that low level of agricultural mechanization is a challenge affecting the economy, in other words the various tools necessary for production and distribution of agricultural products have not been really utilized, $70(35 \%)$ of the respondents believe the subsistence level of production is a challenge affecting the economy, $127(63.5 \%)$ believe corruption to be a challenge affecting the economy, 90 (45\%) agreed that the economic recession is the challenge affecting the economy and $52(26 \%)$ believe insurgency is a challenge affecting the economy while $2(0.14 \%)$ agreed that there are other reasons challenging the economy. Based on the response from the respondents, the sequence of how much this challenges affect the economy from the highest to the lowest is corruption, Corruption is prevalent in the agriculture sector as well as other sectors in the nation. This particular issue has wreaked havoc in the agriculture sector and the nation at large. Next is low level of agricultural mechanization, economic recession, subsistence level of production, insurgency and other factors.

Figure 2: What are the challenges faced by farmers? 


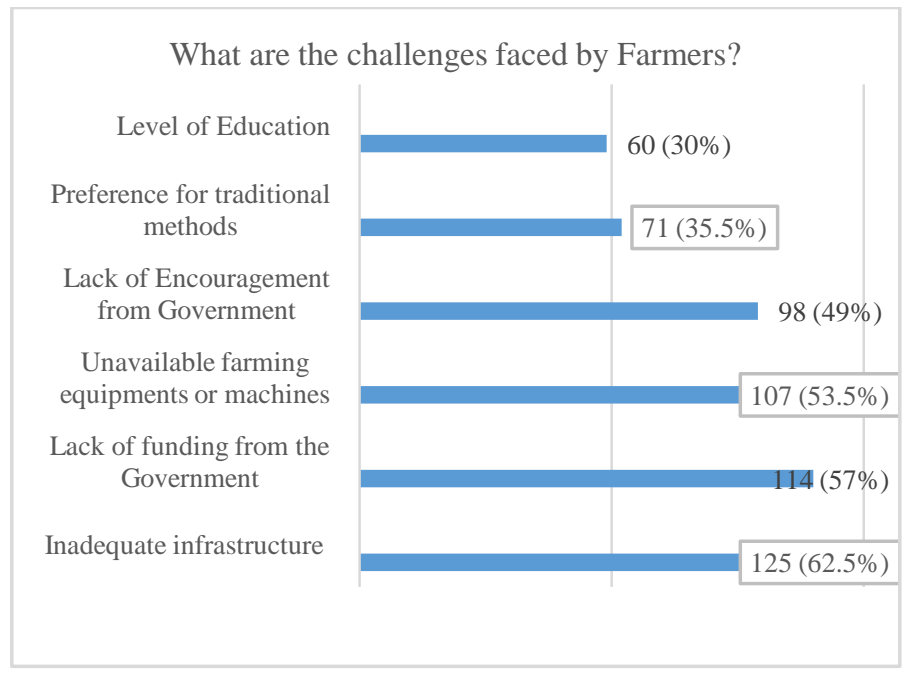

Field Survey, 2021

The chart above on the challenges faced by farmers shows that $125(62.5 \%)$ of the respondents believe that inadequate infrastructures is a challenge faced by farmers, these infrastructures refer to all the basic services needed to facilitate production, procurement, processing, preservation and trade, $114(57 \%)$ believe it is lack of funding from the government, $107(53.5 \%)$ believe it is the unavailability of farm equipment and machineries, 98 (49\%) believe it is the lack of encouragement from the government, 71 (35.5\%) believe it is the preference of traditional method by farmers and lastly, $60(30 \%)$ believe the level of education of farmers could be a challenge in some cases. The level at which this challenges affect farmers from the highest to the lowest is, inadequate infrastructure, lack of funding from the government, unavailable farming equipment or machine, lack of encouragement from government, preference of traditional methods and level of education.

How agriculture can be restored as a component of economic growth.

Table 12: How can Agriculture serve as tool for poverty reduction and economic growth?

\begin{tabular}{|c|c|c|c|c|c|c|}
\hline S/N & OPTIONS & SA & A & N & D & SD \\
\hline 1 & $\begin{array}{c}\text { Agriculture should be practiced } \\
\text { on a large scale }\end{array}$ & 168 & 25 & 0 & 7 & 0 \\
\hline 2 & $\begin{array}{c}\text { There should be specification } \\
\text { on what part of agriculture to } \\
\text { engage in }\end{array}$ & 51 & 106 & 8 & 32 & 3 \\
\hline 3 & $\begin{array}{c}\text { Agriculture should be made } \\
\text { attractive to youths }\end{array}$ & 99 & 72 & 1 & 16 & 12 \\
\hline 4 & $\begin{array}{c}\text { Government should be ready to } \\
\text { support }\end{array}$ & 169 & 24 & 0 & 7 & 0 \\
\hline 5 & Mechanisation & 169 & 24 & 0 & 7 & 0 \\
\hline
\end{tabular}

Field Survey, 2021

The table above shows that majority of the respondents believes in restoring agricultural pride, youth should be ready to practice agriculture on a large scale, the government should be ready to support farmers, there should be specialization of roles in term of the particular type of agriculture practice and also agriculture should be made attractive to youths through proper financing, monitoring and evaluation and mentoring where necessary

\section{DISCUSSION OF MAJOR RESEARCH FINDINGS}

It is evident in this study that Agricultural development is needful for any country's economy to grow. It was affirmed by majority of the respondents that participated in this study that agricultural development has greatly helped in stimulating industrial growth which in turn helps to boost the economy. Also, Figure 4.2 and Figure 4.3 shows how significant mechanized farming is on the earnings of individuals as very few individuals earned more than N60,000 from agriculture, others were earning between $\mathrm{N} 10,000$ and $\mathrm{N} 30,000$. Apparently, compared to traditional methods, the number of those involved in mechanized farming are lower and it is evident in the amount earned by these people in their agriculture.

Based on the study carried out, the researcher discovered the effects of agricultural development on the economic growth such as contribution to National Income, source of food supply, pre-requisite for raw materials, relief from shortage of capital, helpful in phasing out economic depression, etc. However, it was evident that certain barriers like lack of finance, inadequate agricultural facilities, pests, etc. still hinders the economy growth.

Firstly, the variables used to measure the effects of agricultural development on the economy were mainly the type of farming these individuals practice and the amount they earn from agriculture monthly, a lot of individuals still make use of traditional methods in farming which is not really helping in large scale production, this is due to the fact that a majority of participants affirmed that there are inadequate agricultural facilities and insufficient finance to cover the cost of purchasing these modern technologies.

Also, some respondents affirmed that in addition to the total support from government such as provision of capital, provision of land, etc. there should first be availability of modern facilities then easy access to these modern facilities so as to switch to the mechanized system of agriculture.

Mechanized system of agriculture has great and positive effects on the economy as it helps to provide mass production or production on a large scale and this leads to great sales. The structural change theory used in this study which is simply a modification or change in the ways an economy functions or operates. Presently, the current driving force of this structural change is globalization. This structural change does not just happen in a flash, it has to first start with a shift from primary to secondary production and finally the tertiary production. In other words, there has to be a shift from traditional methods of agriculture to the modern or mechanized system of Agriculture. Apparently, availability of land is very important for this transformation to occur because for one to be able to 
produce on a large scale, more land is required, also technology is crucial in the process of structural change because in order to drift from subsistence method to urbanized method, technological methods and mechanisms has to be adopted.

Consequently, this study has been able to show us that Agricultural development can also serve as a source of income since we still have an ever-increasing rate of unemployment in the nation. Also, it also provides raw materials for producing both agriculture-related and non-agricultural products. Conclusively, it is important to know that in other areas/zones where agriculture may not be able to flourish, for example, riverine areas, it is important that each zone should be productive in their area of expertise /strength, as this will enable them thrive economically and in other areas, perhaps, oil exploration, coal, gold, etc. In so doing, both the Internally Generated Revenue (IGR) and the country will increase and economic growth will be visible.

\section{CONCLUSIONS}

From the findings of this study the following conclusions were made: Promoting agricultural development and actualizing it effectively helps to influence the economy. In addition, the adoption of mechanized farming is absolutely important in promoting agricultural development as it serves as a major aspect of agricultural development, easy access to these facilities is essential for any community to develop.

Also, adequate funding and encouragement from the Government helps the farmers greatly and makes the workload easier for them to execute. Public awareness and enlightenment programmes helps people understand how agricultural development helps a great deal in boosting the economy. Ultimately, agricultural development or the adoption of mechanized system of farming in fact helps to boost the growing economy.

\section{RECOMMENDATIONS}

The recommendation gotten from the research study is that indulging in agricultural activities is very beneficial not only as an individual but as a whole. Not only does it help one to feed adequately and consistently, it also serve as a way of earning money Also, indulging in agricultural practices and adopting the mechanized method of agriculture also go a long way in producing on a large scale and making these agricultural products available for commercial purposes. In the end, engaging in agricultural activities and producing on a large scale through the use of modern technology helps to boost the economy in Ilorin. It is highly recommended by this research, that its finding be properly adopted and implemented. In spite of this, the following recommendations have been made:

- Awareness programmes should be made to enlighten individuals on the importance of agriculture and how it is necessary to participate in agricultural activities. In addition to this, individuals should not just settle for the traditional method but adopt the modern method as it brings more yields.

- Farmers and others involved in agricultural activities should be encouraged by the Government. This could be done by giving enough support and making adequate funds available to these individuals because a lot of individuals are willing to engage in mechanized farming but the insufficiency of capital and adequate funding has prevented them from achieving this. More so, the Government should recognized how effectively these individuals are working and boosting the economy.

- In addition to adequate funding from the government, other sources should be made available for these individuals to be able to get funds for their agricultural practices, such as, agricultural development bank, farmers' cooperatives, also, borrowing from farmers group, men/women group, and money lenders, one could also borrow from family members/relatives.

- More agro-allied industries should be created in other to stimulate industrial and economic growth

- More importantly, mechanized farming should be adopted by all or by most individuals as this helps production to a large extent. Also, easy access to these facilities should be made available to the people.

- Storage facilities should be made available for safe storage of these agricultural products.

Developing nations like Nigeria should put more attention on the agricultural sector as it is the only sector that provides the convenient means to enable industrial development since all other sectors one way or the other are dependent on agriculture for sustenance. Not only does this study present the methods and structure of the model but also shows the econometric analysis and facts and the hindrances to effective agricultural performances and proffers appropriate solutions. The commercialization of agricultural products and its ventures has been seen as a great way to promote economic development and sustainability in a nation.

In order to refurbish Nigeria's declining economy, the government established the Economic Recovery and Growth Plan (ERGP) to help with the nation's economic recession. In an attempt to halt certain issues in the nation such as unemployment, food security, economic depression, foreign exchange, the ERGP implemented agriculture as a major sector of the nation's economy. To achieve the goals of this programme, i.e. the ERGP, it must be reinforced consciously.

\section{REFERENCES}

[1] Aluko, S. (2004). Making Natural Resources into a blessing rather than a curse: in covering oil. A Reporter's Guide to Energy and Development. Open Society Institute.

[2] Ayoola, G.B. (2001), Essays on the Agricultural Economy 1: A Book of Readings on Agricultural development Policy and Administration in Nigeria: Ibadan: TMA Publishers. 
[3] Bakare, A S. (2013) 'an econometric analysis of sustainable agriculture and rural development in Nigeria: A Vector Autoregressive Approach (VAR). Journal of Agricultural Economics and Development,' 2(5), 184-193.World Bank, (2014). World Bank Development Report

[4] Berhanu, A. (2014, June). Sir W. Arthur Lewis, the College of William and Mary No. 152

[5] Cambridge, Massachusetts, Harvard University Press.

[6] Cardno (2017) Agricultural development as a key role in food security and economic development in most of the world's population in rural area.

[7] Chauvin, N., Mulangu, F. \& Porto,G. (2012, February). Food Production and Consumption Trends in Sub-Saharan Africa: Prospects for the Transformation of the Agricultural Sector. UNDP Working Paper for African Human Development Report, pp. 1-74.

[8] Christiensen, R P., and Yee, Y. (1964), 'The Mechanics of Agricultural Productivity and Economic Growth,' Journal of Farm Economics, 46(5), 1051-1061.

[9] ECA-OECD Review 2005

[10] European Commission (2018) Sustainable agriculture and rural development policy-Agricultural development. International cooperation and development.

[11] Ewetan Olabanji, Fakile Adebisi, Urhie Ese and Oduntan Emmanuel (2017), "Agricultural

[12] Falola, T. \& Heaton, M. (2008). A History of Nigeria. New York: Cambridge University Press. pp. 183.

[13] Gustav, .R. (2004). Arthur Lewis' Contribution to Development Thinking and Policy, Yale University, Center Discussion Paper No. 891

[14] Ideba, E E., Iniobong, E., Otu. W. and Itoro, N. (2014), 'Analysis of Agricultural Public Capital Expenditure and Agricultural Economic Growth in Nigeria,' American Journal of Experimental Agriculture, 4(4), 443-456.

[15] Iyoha, M. \& Oriakhi, D. (2002). Explaining African Economic Growth Performance: The Case of Nigeria. Revised Interim Report on Nigerian Case Study prepared for the African Economic Research Consortium Research Project titled "Explaining African Economic Growth Performance".

[16] Joseph E. Stiglitz (2015). The sinking of the World Economy

[17] Kindleberger, Charles P. (1967). Europe's Postwar Growth: The Role of Labor Supply,

[18] Labour Force Statistics, 2010. Nigerian Bureau of Statistics. 2010. Archived from the original on 24 April 2015. Retrieved 22 June 2015.

[19] Lewis, W. Arthur (1954). "Economic Development with Unlimited Supplies of Labor,"

[20] (1955). The Theory of Economic Growth, Homewood, Illinois, Richard D. Irwin.

[21] (1969). Aspects of Tropical Trade 1883-1965, Stockholm, Almquist and Wicksell.

[22] (1977). The Evolution of the International Economic Order, Princeton, Princeton University Press.

[23] Manchester School of Economic and Social Studies, Vol. 22, pp. $139-91$.
[24] Mustapha, A. A. (2017, June). Nigeria's Economic Growth: Past, Present and Determinants, American Research Institute for Policy Development

[25] Noel, T. P. (2012, March). The importance of Economic Growth

[26] NwachukwuI (2008) Planning and evaluation of agricultural and rural development project. Lambhouse publishers. p. 1-6.

[27] Nzeka, U. (2013). Grain and Feed Annual; Annual Report 2013. USDA Foreign Agricultural Service.

[28] Odetola, T. And Etumnu, C. (2013), 'Contribution of Agriculture to Economic Growth in Nigeria, International Food Policy Research Institute (IFPRI), Abuja, Nigeria,'

[29] Odoh, P. (2014, May) Challenges of Agriculture in Nigeria Economy: A Bane to Food Security. Federal Polytechnic, Zamfara State, Nigeria.

[30] Olomola Ade S. (2007) "Strategies for Managing the Opportunities and Challenges of the Current Agricultural Commodity Booms in SSA" in Seminar Papers on Managing Commodity Booms in Sub-Saharan (: Africa: A Publication of the AERC Senior Policy Seminar IX. African Economic Research Consortium (AERC), Nairobi, Kenya

[31] Omorogbe O, Jelena Z, Fatima A (2014) The role of Agricultural development in the economic growth of Nigeria. European Scientific Journal 10(4).

[32] Omorogbe, O., Jelena, Z. \& Fatima, A. (2014, February). The role of agriculture in the economic development of Nigeria. American University of Nigeria, Nigeria.

[33] Otaha, J. (2012). Dutch Disease and Nigeria Oil Economy. African Research Review, 6 (1), 82-90.

[34] Output and Economic Growth in Nigeria “, Journal of African Research in Business \& Technology, Vol. 2017

[35] Pasinetti, Luigi L. (1981). Structural Change and Economic Growth. Cambridge: Cambridge University Press. ISBN 0-52127410-9.

[36] Proceedings of The 18th Annual African Econometric Society (AES), 2013, at the session organized by the Association for the Advancement of African Women Economists (AAAWE), Accra, Ghana

[37] Researchclue.com (2013) The impact of Agricultural development on economic growth of Nigeria. Home for Nigerian researchers.

[38] Reynulds, Researchclue.com (2013) The impact of Agricultural development on economic growth of Nigeria. Home for Nigerian researchers.

[39] Sekunmade, A. (2009). The effects of petroleum dependency on agricultural trade in Nigeria: An error correlation modeling (ECM) approach. Scientific Research and Essay, 4 (11), 1385-1391.

[40] Structural Change Definition | Investopedia. Investopedia. Retrieved 2016-03-04.

[41] Sulaimon Aremu Yusuf (2014); Role of agriculture in economic growth and development: Nigeria perspective, Lagos, Nigeria

[42] Sulaimon, A. (2014, February). Role of Agriculture in Economic Growth \& Development: Nigeria Perspective. University of Lagos, Lagos, Nigeria.

[43] Williams, S.K.T. (1978). Rural Development in Nigeria. Ile-Ife University of Ife Press, Nigeria, 129pp. 